\title{
An Observation on the Characteristics of Design and Aesthetics of Balinese 'Sacred Cloths'
}

\author{
Langi, Kezia-Clarissa $\cdot$ Park, Shinmi ${ }^{+}$ \\ Master Candidate, Dept. of Clothing \& Textiles, Andong National University \\ Associate Professor, Dept. of Clothing \& Textiles, Andong National University ${ }^{+}$ \\ (received date: 2017. 1. 2, revised date: 2017. 3. 7, accepted date: 2017. 4. 11)
}

\begin{abstract}
The uniqueness of Bali is inseparable from its culture and religion. Embedded in the cultural environment, textiles become one of the most important aspects in Balinese life as it is used as a medium in sacred ceremonies. Balinese textiles are made and used under special conditions according to Hindu teaching.

This paper aims to observe the aesthetics of Balinese sacred cloths that are seen in their techniques, colors, and patterns. Quantitative research included in this study is based on 261 images taken from literature review and Museums. Field research was done in eastern part of Bali.

This paper has divided the era between ancient and modern times. The ancient era before the 20th century used textiles for religious purposes. Modern era started from the colonialization period by the Dutch in Bali during 1910-1942 added economic values to the textiles. The independence of Indonesia in 1945 created Balinese textiles as a unifying value as one of the identity of Indonesia.

The techniques are classified as Weft Ikat, Double Ikat, weave with Supplementary Weft, and Prada. The colors of the ancient era are 'fixed' with the restriction of the colors red, black, and white. The colors of modern era are 'festive' with combination of yellow, green, blue, and purple. The characteristics of patterns are geometric, natural, human, and animal groups.

Field research in this paper observes Klungkung Village that produces Endek and Songket cloths. The aesthetics of Endek cloth is 'royal statement' and Songket cloth is a 'cultural heritage.' Nusa Penida Island produces Cepuk cloths and is a 'protective guardian.' Satria sub-district produces Prada cloths and appears to be an 'opulence charm.' Lastly, Tenganan Village produces Geringsing cloth which possesses a 'legendary legacy.' To sum up, Balinese sacred cloth essence is a balance of tradition and modern.
\end{abstract}

Key words: aesthetic characteristics(미적 특성), Balinese sacred cloths(발리 신성직물), color(색깔), pattern(패턴), technique(테크닉)

This research is a part of the master's thesis.

Corresponding author: Shinmi Park, e-mail: fashion@anu.ac.kr 


\section{I . Introduction}

This chapter is the foundation of this paper. It introduces the background information of Bali and its religious values that have influenced their textiles. It also consists of the literature review and research proposition. In addition, this chapter shows the aim and methodology of this paper.

\section{Background Information}

Bali is the only Hindu island in Indonesia. Based on the community structure, Balinese people are separated into the Bali Aga and Bali Hindu. The Bali Aga, or the Mountain People, are the pure Balinese who migrated to the mountains during the occupation by the HinduJavanese during the rule of the Majapahit Kingdom(circa 1500). During that time, Hindu religion started in Bali. Bali Hindu is characterized by the assimilation of Hindu religion and the local animist beliefs(Wrońska-Friend, 2015). Due to its religion, the life of Balinese society is filled with custom laws and ceremonies that go along with everyday activities. From this influence, from the day a Balinese is born until they die, ceremonies are held in order to create a religious balance in their life. These ceremonies require special textiles to complete the rituals.

Creating textiles is considered an act of art. In Bali, the production of art is based on the balance of Tri Hita Karana, or the three reasons of happiness, which are the balance between human and God, between human and human, and between humans and their surroundings(Soedjatmoko, Damais, \& Saputra, 1993). In fact "In Bali, the creation and presentation of art is a devotional act"(Davies, 2007, p. 23). The entire act of art comes back to God.

Culture contributes a huge part of Balinese life and all of their art is intended to be given back to Tri Murti, the deity of Brahma, Vishnu, and Shiva(Soedjatmoko et al., 1993). Balinese of all ages and social classes learn and produce art. In the textile making process, men and women create textiles side by side. The essences of traditional textiles are the value and high craftsmanship of the weavers. This creates the difference of traditional Balinese textiles from machine-produced textiles.

\section{Literature Review and Research Proposition}

The literature review analyzed specific Balinese textiles with case study approaches. This paper examines the aesthetics of Balinese sacred cloth. The literature review studied in this paper focuses on Balinese textiles based on field research in Eastern Bali. This creates a new body of study material.

Widiawati and Rosandini(2012) did a case study of natural dyeing in Geringsing woven cloths. Natural dyeing in Indonesia has its own characteristics and uniqueness. Focusing on the natural dyeing of Geringsing woven cloths, this paper examined the relationship of color and philosophy of Bali. In addition their paper observed the process of dyeing from the locals.

Nabholz-Kartaschoff(2008) did a case research on the so-called Kain Sembiran. However, the textile did not come from the Sembiran area at all. The case study was done by observing the history of Bali and writings from traders. That paper found that the original textile from Sembiran consists of simple lines and a cloth 
called lamak.

Bjork(2013) examines the relationship between mythology and weaving, studying the hospitality of color healing presence in ceremonial Balinese textiles and the relationship between Balinese and Greek mythology. The sense of mythology weaves through the textiles, creating myth fabrics for one's life. That paper also shows how the dualism in Balinese myth and the combination of Balinese colors gives balance and healing.

\section{Research Aim and Methodologies}

This research aims to observe the aesthetics of Balinese sacred cloths. The paper addresses three fundamental questions. Firstly, what are the developments of Balinese textiles? Secondly, what are the design characteristics of Balinese sacred cloths? Lastly, what are the aesthetics of Balinese sacred cloths based on the field research?

The paper observes the ancient Balinese sacred cloths based on literature research, while modern Balinese sacred cloths are examined by the field research. Quantitative research included in this study reveals 261 images taken from the Museum of Bali and previous studies. Qualitative research has been done by the field research(from 3 to 11 July, 2015, and from 17 to 23 January, 2016) in one dyeing production house in Klungkung Village and nine weaving production houses in Tanglad, Klungkung, and Tenganan Village as well as Satria Sub-district in the eastern part of Bali, as well as from the Museum of Bali, and Pekan Kebudayaan Bali 2015, an annual art festival in Bali.

The research determines the design characteristics and aesthetic in Balinese sacred cloths. It observes the spirituality, developments, and func- tion of Balinese textiles. Spirituality plays a huge role in Balinese life, it determines why, when, and how the textiles are created. The developments of Balinese textiles portray the function transition progress of the ancient era into the modern era. This progress develops the characteristics and purpose of Balinese sacred cloths.

The design characteristics of Balinese sacred cloths are studied based on techniques, colors, and patterns. Balinese sacred cloths were chosen by their function in ceremonies, as the medium of ancestors, healing purpose, evil-repellent, ceremonial costume, and temple decoration.

Finally, this paper analyzes the design aesthetics of Balinese textiles founded in both the literature review and field research.

\section{Spirituality, Developments, and Functions of Balinese Textiles}

This chapter discusses the spirituality, developments, and functions of Balinese textiles. Balinese textile developed their functions and characteristics as a part of a spiritual medium.

\section{Spirituality}

Spirituality is a fundamental aspect in Bali. During the ancient era of Bali, Balinese practiced their own animism in which they worshiped the ancestors of the land and the sea(WronskaFriend, 2015). Later, this indigenous animism fused with Hinduism and created the religion of Hindu Dharma.

Balinese society created the philosophy of $\mathrm{de}^{-}$ sa-kala-patra, referring to orientation in space, time, and social strata. They also created a calendar which determines the right time, the right 
space, and the right social situation and standing (Daerdia, 2012). This system is believed to create a balance between sekala and niskala. Sekala is the secular, the visible forces, while niskala is the invisible force. The land and people maintain and balance this sacredness in Bali. This philosophy is applied in textile making and created sacred cloths that serve in maintaining the balance of sekala and niskala.

Another philosophy is the nawasanga $\langle$ Fig. 1〉. The Nawasanga is an entire system of cosmos that is divided into eight cardinal directions or rulers(gods) and the ninth point is at the center. According to Darta, Couteau, \& Bréguet(2013), "Nawasanga is also called the sacred compass rose or the mandala of the world." (p. 42). Bjork (2013) claims that nawasanga represents "all of the rulers from a finite set of elements including colors, letters, numbers, sounds, and forces" (p. 83). The nawasanga is used in rituals and textile making.

"To truly enter into the realm of sacred textiles in Bali, one must first define and contextualize sacredness in textiles and sacredness in Bali (Daerdia, 2012, p. 4)." The ideologies of nawasanga are embedded in the textiles' function, technique, pattern, and color. Textiles are more than just cloth. Textiles are a medium of the divine universe, and their material manifests the visible force(Hauser-Schaublin, Nabholz-Kartaschoff \& Ramseyer, 1991). This semiotic medium is infused with niskala and used in exorcism, purification, spiritual protection, and offering. In addition, there are sacred textiles for royalty and they are forbidden to be used by normal citizens. This creates textiles as a medium of praying, as clothing for religious events and as clothing for temples. In Balinese society, caste is the basis of social status; therefore textiles also played the role of status divider.

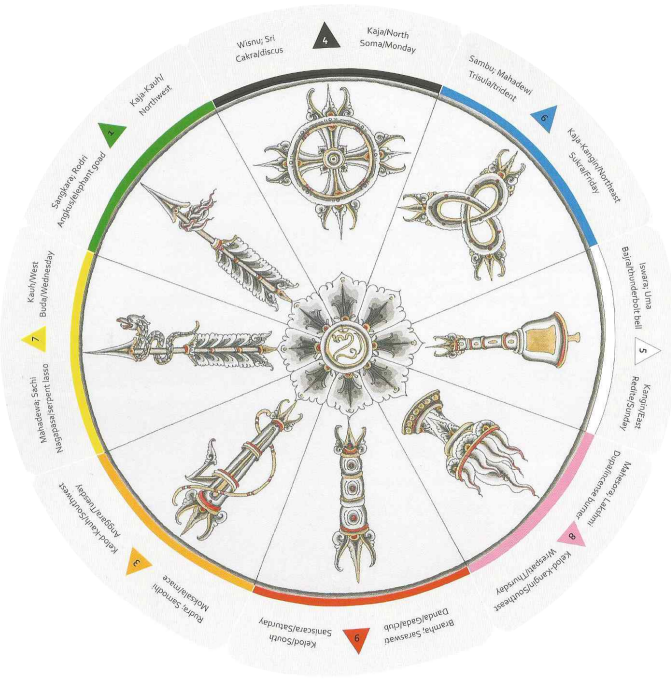

〈Fig. 1〉 Nawasanga

(Darta et al., 2013. p. 42)

\section{Developments and Function}

Balinese cloth developed during two periods: the ancient and modern era. This paper specifies the ancient era as the time before the $20^{\text {th }}$ century and the modern era as the colonization by the Dutch period and independence of Indonesia period. The ancient and modern era is divided by its religious belief. The ancient era practice the local animism and modern era was influenced by the common religion(e.g. Buddhism, Hinduism, Islam, and Christianity). The characteristics of Balinese textiles during these periods are expounded below $\langle$ Table 1$\rangle$.

\section{1) Ancient Era: Before 20th Century}

In this period, Balinese textiles were made religiously. The spiritual act started from the 
moment a material was chosen, deciding the pattern, tying or drawing the textiles, and weaving, until the moment the cloth was cut. The society believed it was necessary to pray and to give offerings in order to avoid mistakes. Therefore, they were able to produce perfect sacred cloths worthy to god(Sumiartini, 2015). It is known that a mother would start to create sacred cloths for their children in the time between their gestation until they turned ten years old, in order to provide them with a costume for rituals(Sumiartini, 2015). The act of textile making reflects the piety of the creator.

In this era, Balinese textile were limited to three colors, Created by natural materials with a small, complicated, and repetitive patterns, Balinese textile took months or even years to complete〈Fig. 2, 3, 4, 5, 6〉.

\section{2) Modern Era}

The modern era of Bali is separated into the Dutch colonization period in 1910-1942 and the independence of Indonesia in 1945. Each of these periods contributes different functions and influences.

\section{(1) Colonization by the Dutch: 1910-1942}

The colonial period of the Dutch created a huge change in Balinese textiles. The Dutch were captivated by the beauty of Bali and promoted it as a tourist attraction(Covarrubias, 1937). This is the reason why the Dutch decided to keep the island as it was, also letting the locals continue their faith in Hinduism and sending anthropologists to study the culture.

This era was a starting point of the Bali industrial revolution. With the tourism provided by the Dutch, the interest in Balinese textiles gained recognition by the international tourists. Businesses and new technologies changed Balinese textile production in that period. Because of the high demand for the textiles, the Dutch provided weaving machines that can produce meters of fabrics in a short time. Textiles have a new role as an economic commodity. Unfortunately, rather than being blessed, textiles were sold to tourists in order to pay taxes to the Dutch.

During this era, Balinese textiles experienced innovation of new synthetic dyeing that cut the time of the years it took for natural dyeing to absorb into only a few hours. In addition, bigger patterns were created to save production time〈Fig. 7, 8, 9, 10, 11〉.

\section{(2) Independence of Indonesia: 1945-2016}

After the independence of Indonesia, each Indonesian traditional textile became a part of Indonesian identity. Through textile, Indonesia's 300 ethnic groups can be united. In this era, traditional textiles function changed into formal uses, such as uniforms for government, souvenirs, and formal attire.

Balinese textile became a commodity item for economic reasons. As a result, Balinese textile's pattern widely use contemporary or borrowed patterns. In this era, the revival of natural materials and dyeing began to appear. Eco-friendly issues also started to appear $\angle F i g .12,13,14,15$, 16). Despite these changes, textile production for religious reasons is still used to complete spiritual ceremonies. 
〈Table 1〉 The Developments and Functions of Balinese Textiles by Era

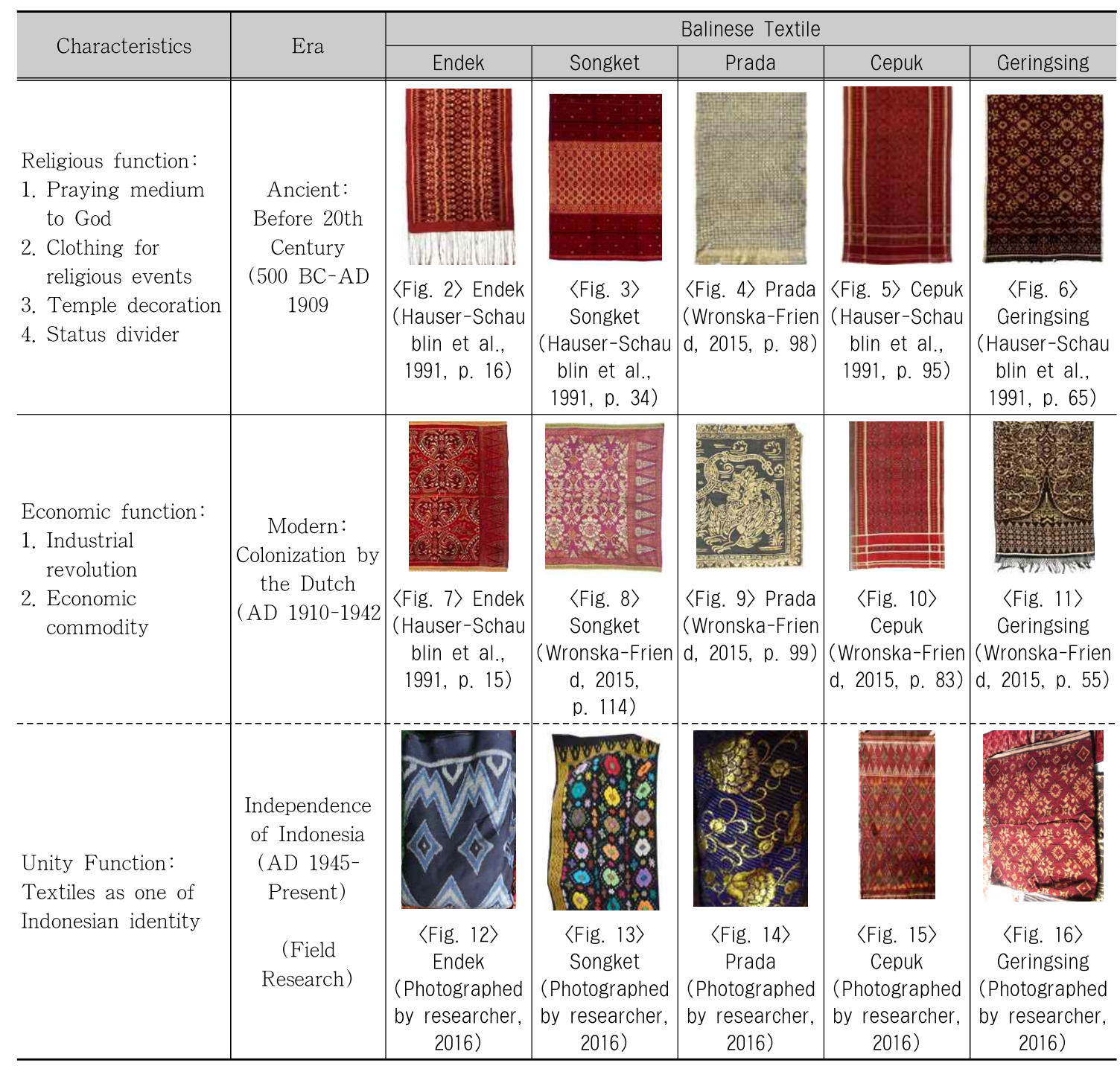

(Table by researchers, 2017)

\section{Design Characteristics of Balinese Textiles.}

Design characteristics of Balinese textiles are studied based on their techniques, colors, and patterns. The characteristics are studied based on the Balinese Hindu religion.
1. Techniques : Hindu Dharma Dedication

The technique of creating Balinese textiles requires a special ritual of praying, fasting, and offerings to the deities. These religious acts are done in order to be blessed by the deities and to avoid mistakes while creating the textiles. It is 
believed that the true creators of a textile are not solely the weavers, but the people responsible for the tying and dyeing process (WrońskaFriend, 2015). In Bali, the sacred cloths are only created on the "back strap loom" called cagcag. The techniques of pattern making in Bali covers Weft Ikat, weave with Supple- mentary Weft, Double Ikat, and Prada.

\section{1) Weft Ikat: Worship}

Ikat, which means 'to tie' or 'to bond', is a pattern-making method that ties the yarns in specific compositions before dying. Weft Ikat means, the weft part of the cloths are tied according to a specific pattern and then immersed into a dyeing solution(Gillow \& Dawson, 1995) $\langle$ Fig. 17〉. Weft Ikat technique was influenced by the Hindu-Buddhist religion, which was bought by the Chinese and Indian merchants. This binding technique is the first weaving technique made in Bali. It is believed that the goddess of Ratih taught the citizens how to weave.

\section{2) Weave with Supplementary Weft: Status}

The weave with Supplementary Weft technique is a technique adds additional weft yarns into the weaving to create a pattern. In Bali, it is called Songket. The technique was bought by monks studying in Palembang(Sumatra) to Bali in the $7^{\text {th }}$ century(Hauser-Schaublin et al., 1991). These patterns are created directly on the cagcag loom. The designed patterns are first created by thin long sticks that are then removed one-by-one $\langle$ Fig. 18〉. This technique is used for maturity ceremonies such as tooth filling and marriage. In addition, it also shows the social status of the wearer.

\section{3) Double Ikat: Spiritual}

Double Ikat is a unique technique using both warp and weft Ikat to create the pattern. This is considered the most difficult technique among Ikat techniques. The yarns should be perfectly tied and matched between the warp and weft to produce a visible pattern〈Fig. 19〉. The Indian merchants from Gujarat introduced this technique through trading Patola(Indian double Ikat textile) cloth to the Balinese.

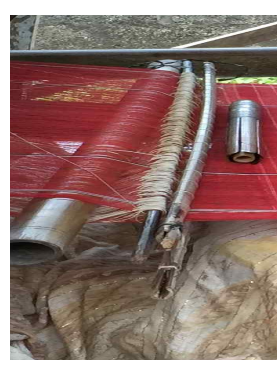

$\langle$ Fig. 17〉

Weft Ikat (Photographed by researcher, 2015)

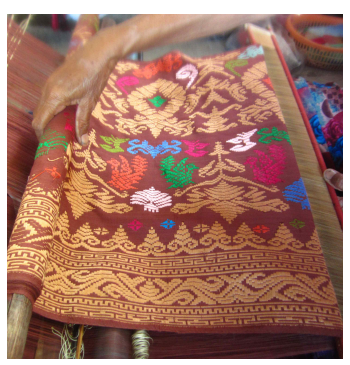

〈Fig. 18〉

weave with Supplementary Weft

(Photographed by researcher, 2015)

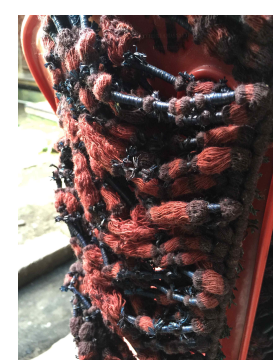

〈Fig. 19〉

Double Ikat (Photographed by researcher, 2015)

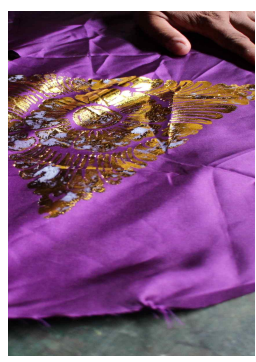

〈Fig. 20〉 Prada (Photographed by researcher, 2016) 
〈Table 2〉 The Color Characteristics of Balinese Textiles

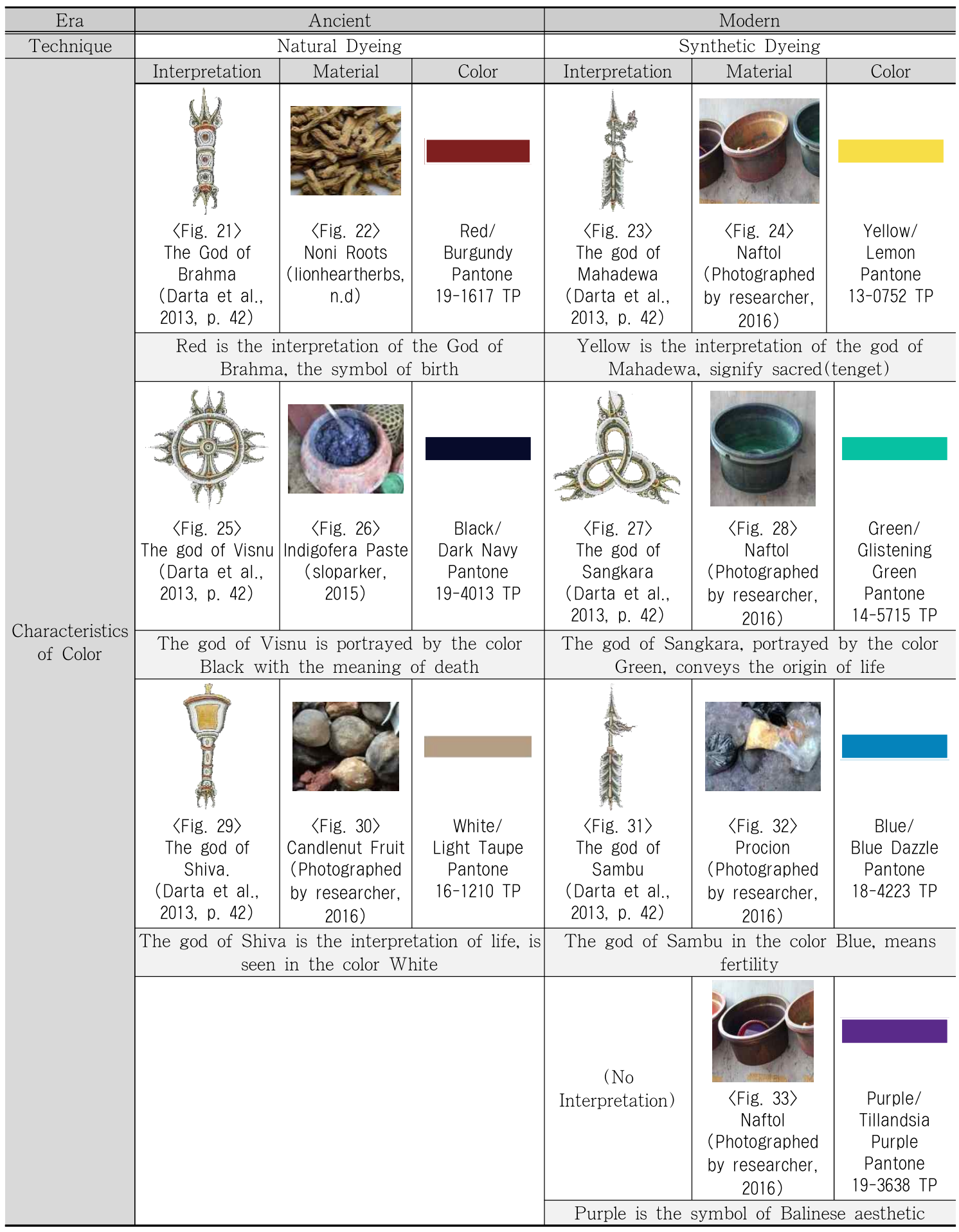

(Table by researchers, 2017) 


\section{4) Prada: Royal}

Prada is a technique of patterning using glue and gold flakes. The glue is made from mixture of albumen or linseed oil mixed in yellow earth(ruddle) (Gillow \& Dawson, 1995). Creating Prada involves drawing a pattern using glue and to dust the gold on top of it. Today, Prada is made using gold foil created by silk printing technique〈Fig. 20〉. Unlike other types of textiles in Bali, this technique is performed by only men(Widana, 2016).

\section{Colors: Balance of Nature}

Colors of Balinese textiles are classified by era(ancient and modern). Colors in Bali represent the gods seen in their religion. The gods of the color are based on the nawasanga $\langle$ Fig. 1 $\rangle$. The colors in this paper are standardized by Pantone's color code(Pantone, 1992)〈Table 2〉.

\section{1) Ancient Era: Warm Tone}

The ancient era, before the $20^{\text {th }}$ Century, has a warm tone. The color is restricted to three colors, red, black, and white. These colors are the representation of the three gods of Brahma 〈Fig. 21〉, Vishnu〈Fig. 25〉, and Shiva〈Fig. 29〉, referred to as the Tridatu, meaning 'three powers'. The concept also comes from 'blood', 'charcoal', and 'chalk' or in Balinese language, 'getih', 'areng', and 'pamor'(Widiawati \& Rosandini, 2012). These colors are also the representation a rice grain(Daerdia, 2012).

Based on the Pantone color code and dyeing material, the color red or in the Pantone color burgundy 19-1617 TP is produced from noni roots $\langle$ Fig. 22〉. Black(in Pantone color dark navy
19-4013 TP) is made from indigo leaves (Fig. 26). The color white(in Pantone color light taupe 16-1210 TP) is created from the oils of candlenut fruit〈Fig. 30〉. The color red coveys birth, black signify death, and white is a symbol of life.

\section{2) Modern Era: Festive}

The modern era AD 1910 until present has a festive color. With the Balinese industrial revolution, Balinese people started to use brighter synthetic colors of Naftol〈Fig. 24, 28, 33〉 and Procion〈Fig. 32〉. However, the new colors are also a part of the interpretation of the Balinese gods seen in the nawasanga $\langle$ Fig. 1 1 . From $\langle$ Table 2〉, the color characteristics of Balinese textiles in the modern era are yellow (in Pantone color lemon 13-0752 TP), which represents the god of Mahadewa〈Fig. 23〉, which means sacred (tenget). Green(glistening green 14-5715 TP) is believe to be the source of everything and represents the god of Sangkara. Blue(blue dazzle 18-4223 TP) signifies fertility is representing the god Sambu〈Fig. 27〉. Lastly, purple(tillandsia purple 19-3638 TPX) represents no god, and signifies Balinese aesthetics.

\section{Patterns: Balinese Ideology}

Balinese patterns are examined through the ancient and modern era. Through different political conditions and textile functions, Balinese patterns acquire different characteristics. Commercially, Balinese sacred cloths are not allowed to be sold. Only the failed sacred cloths that are not worthy of god are sold to tourists (Covarrubias, 1937). There are differences be- 
〈Table 3〉 The Developments of Classification of Balinese Textile Patterns by Era

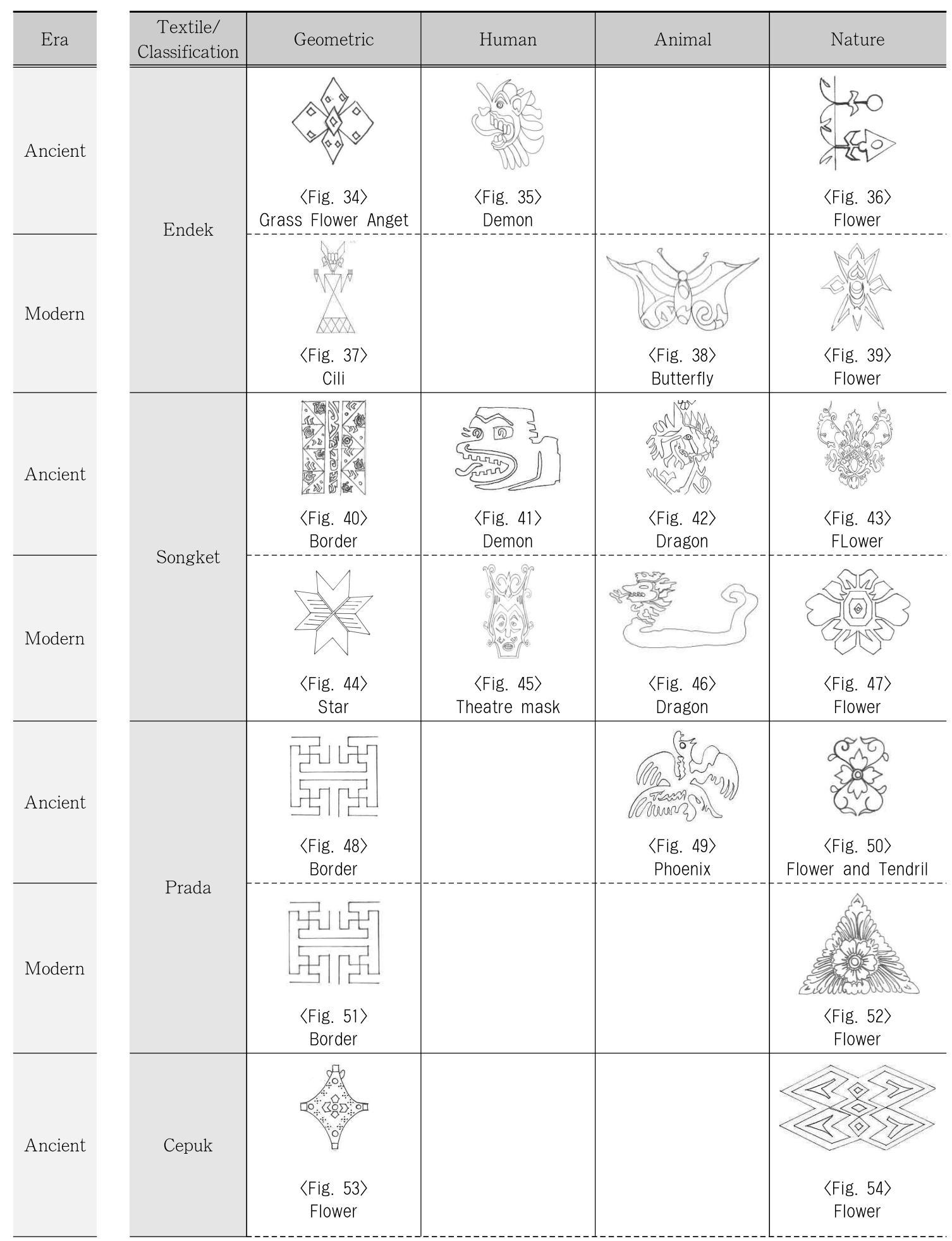




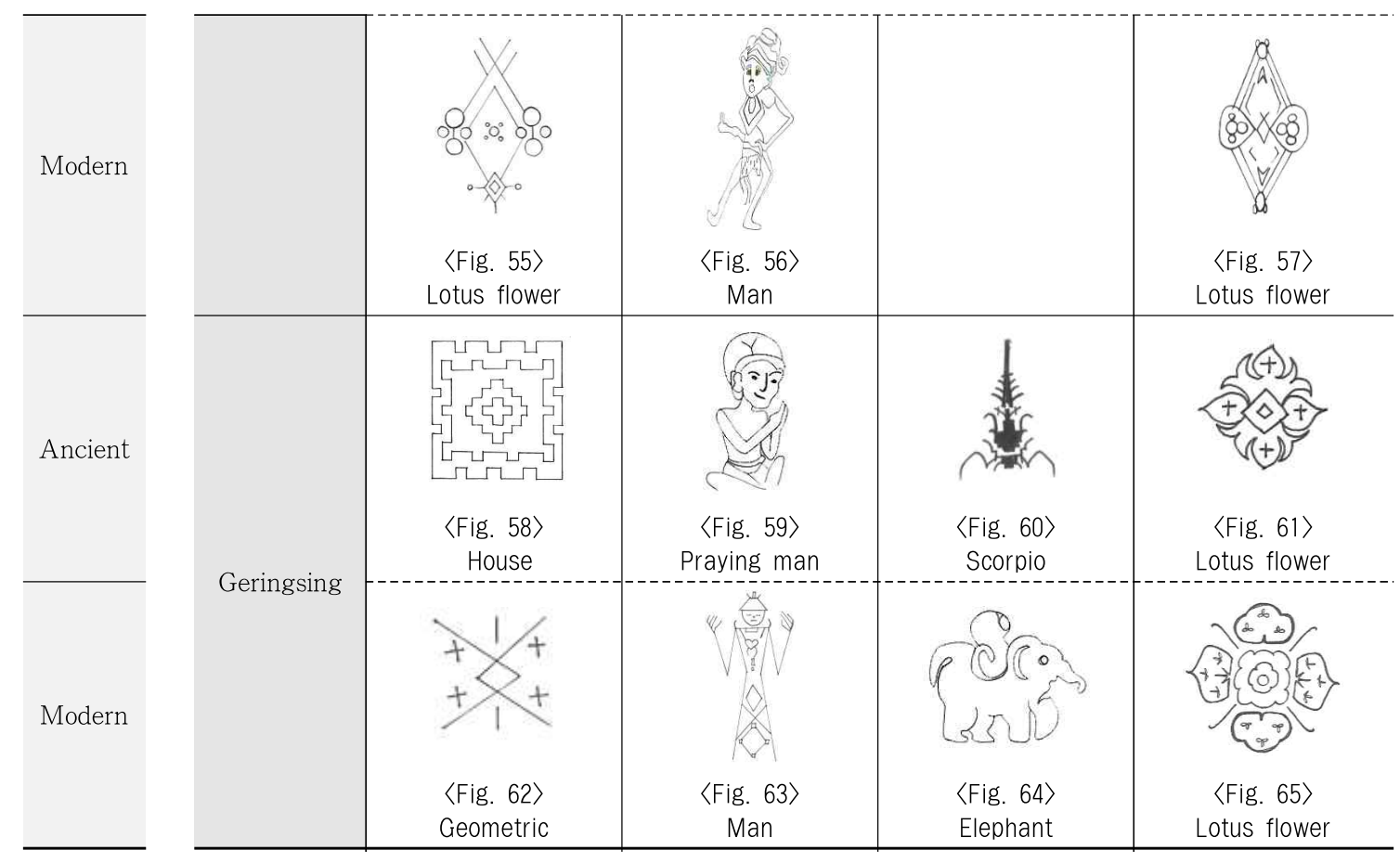

(Illustrated by researchers, 2017)

tween patterns made in the ancient era(fixed) and modern era(complex) $\langle$ Table 3$\rangle$.

\section{1) Ancient Era: Fixed}

Patterns of the ancient era are regulated by the Hindu Dharma religion. Creating a pattern requires a series of religious actions. The pattern maker would give offerings and pray to god for guidance during the process. The patterning process is closely related with the dyeing process. Any mistake during the procedure can create a confusing pattern. Geometric groups are attainable since the patterns are made in a pixel form. However, organic patterns such as circles or curves are difficult to achieve. Therefore if an organic pattern is achieved, the cloth is considered more powerful and valuable.
Each textile is famous for its own pattern. Endek and Songket cloths use tumpal, lotus flower, fish, and Hindu mythology patterns $\langle$ Fig. 34, 35, 39, 40, 41, 42, 43〉. Prada is famous for its lotus flower, phoenix, small birds, vine, and tendrils $\langle$ Fig 48, 49, 50〉. Cepuk motifs are inspired by the symbolic fight between Rangda and Barong; it consists of lotus flowers, geometrical forms, and borders of Barong's teeth〈Fig. 53, 54〉. Geringsing is known for its Patola-inspired patterns, Tenganan Village house, scorpio, lubeng, lotus flowers, and the figure of a praying man〈Fig. 58, 59, 60, 61〉. During this period, small repetitive patterns were commonly made as this shows the piety of the weaver. 


\section{2) Modern Era: Complex}

Since the period of colonization by the Dutch, faster textile production was introduced. As small and complex patterns require a longer production time, bigger patterns with simpler and diverse shapes of human, animal, and nature are made. Although modernization dominates in this era, religiously, the pattern maker continues to give offerings. In addition, Endek and Songket patterns are more diverse with cross-patterns between other cloth's patterns. These developments are more creative and are only available for ceremonial and fashion purposes $\langle$ Fig. 37, 38, 39, 44, 45, 46, 47>. Prada, Cepuk, and Geringsing patterns did not change due to conservative views $\langle$ Fig 51, 52, 55, 56, 57, 62, 63, 64, 65〉.

\section{Aesthetics of Balinese Textiles}

In Bali, instead of the weavers, certain areas established a reputation for their textiles. The entire community is entitled to the honor thereby derived. Balinese sacred cloths are made in the eastern part of Bali. In this chapter, the field research reveals the history, characteristics, and aesthetics of the sacred cloths based on firsthand information. Klungkung Village is well known for its Endek and Songket cloths, Satria Sub-district is well known for Prada cloths, Nusa Penida Island is famous for cepuk cloths, and Tenganan Village is recognized for its Geringsing.

\section{Klungkung Village: Traditional Pride}

Klungkung Village is known for its Endek and Songket production. During the Bali king- dom, the cloths were made by princesses living in local castles called puri and used by royal families to distinguish their royal status. Nowadays, the cloths are used for formal and ceremonial costumes. Endek and Songket are a traditional pride of Bali.

\section{1) Endek[eun-deuk]: Royal Statement}

Endek was worn by royalty as a statement of their position. Earliest Endek dates from the late $19^{\text {th }}$ to early $20^{\text {th }}$ centuries. Endek uses the weft Ikat technique created from cotton or silk. This research observes the production of Astiti, Dian, and Mujur Sari weaving houses. The home company owns five to ten non-machine looms(Alat Tenun Bukan Mesin). The weavers are commonly women, however, in Dian weaving house, male workers dominate the production house. Endek designs are filled with geometric forms. Early figural representation, which is rare, consists of Patola patterns, lions, riders, and elephants(Hauser-Schaublin et al., 1991). Nowadays, Endek designs are created from old Endek patterns or borrowing other cloth's pattern with creative patterns. A consistent month's working can create up to 80 meters〈Fig. 66, 67〉.

\section{2) Songket[song-ket]: Cultural Heritage}

Songket was brought to Bali in the $7^{\text {th }}$ century by monks from Sumatra Island. Bali was a Hindu-Buddhist kingdom; the early ruler of Bali summoned the Hindu and Buddhist priests to assimilate the aspects of Indian culture. This is the reason for the grand display of silk weaving and Songket at the court. Songket has been associated with the highest caste. Songket is made by weave with Supplementary Weft Ikat. 
This research observes Astiti weaving house and their home based weaving. Home weaving production of Songket is done at each weaver's home since the back strap loom does not require too much space and is portable. Only one Songket weaver produces the cloth at the weaving production site. A piece of Songket is made in seven months due to its difficult patterning $\langle$ Fig. 68, 69〉. "Songket was also used in solemn occasions such as processions, weddings, and puberty ceremonies"(Hauser-Schaublin et al., 1991) Today, the elaborated textiles are used mostly for formal and ceremonial wear as well as for wedding costumes.

\section{3) Dyeing Production}

Natural dyeing was essential for Balinese textiles. However, today, synthetic dyeing processes are needed in all weaving production. The rapid and precise coloring is important for a steady business. This study observed Dian Dyeing House Production. This dyeing production receives work orders from around Bali, Lombok, and Java. With only five workers, the production is fast and experienced. The dying process requires 30 minutes to one hour in total. The production uses naftol, proxion, and sulfur as its raw material〈Fig. 70, 71〉.

2. Satria Sub-district, Prada[pra-deu]:

Opulence Charm

Satria sub-district at Klungkung village is known for its heritage Prada making. Over centuries, Prada cloth was brought by Indian and Chinese merchants to Java and Bali. With the belief that the gift is handed down through generations, Prada making is preserved in this area with modern techniques. The opulent cloths were made using gold leaf(Hauser-Schaublin et al., 1991). However, today, Prada is seen to be made of gold foils. The Prada production house that was researched is owned by Anak Agung Widana. There, the Prada technique is used to create religious attributes such as textiles, umbrellas, temple decorations and banners. The Prada technique only requires 30 minutes in its process $\langle$ Fig. 72, 73〉.

\section{Nusa Penida Island, Cepuk[ceu-pook]: Protective Guardian}

Cepuk is known for purificatory, protective, defensive, strength, and magical functions. Cepuk means to be brought face to face with something, as they are used for rituals that interact with erratic divine powers(Hauser-Schaublin et al., 1991). Cepuk was inspired from Patola textiles. Old cepuk is more powerful as its patterns have great similarities with patola. Patola is treated like an object with a soul. As members of the Balinese culture, the deceased are cremated(ngaben). Following this tradition, in 1939, a destroyed cepuk was burned into ashes by the priest of the Pura Dalem(temple) so it would pass on to the next world(HauserSchaublin et al., 1991).

Taglad Village produces cloths over one month of process. The production of Cepuk is personal and created in the citizens own home $\langle$ Fig. 74, 75〉. The production now uses synthetic dye process for coloring. Cepuk composition is a border and centerfield. It is a metaphor of the human being with a head(eled), lips(bibih), smile(kenjing), and eyebrows(alis kening). The flower borders are seen as guardians that protect 
the temple. Lastly, the gigi barong pattern refers to the strength of Barong. Created with Weft Ikat, Cepuk color consists of red, white, and black. However, nowadays with the lack of weavers and interest in weaving, new creative cepuk designs have started to appear.
4. Tenganan Village, Geringsing[gringsing]: Legendary Legacy

The traditional village(Bali Aga) of Tenganan created Geringsing cloths. Geringsing has magical qualities to protect and heal. Geringsing is used for purification, healing, exorcism rituals, shrine decoration, and fabric offering. The strict tradi-

〈Table 4〉 Observation of the Aesthetics of Balinese Textile

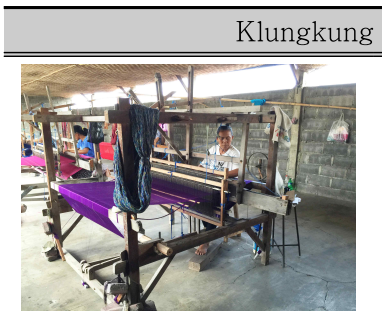

$\langle$ Fig. 66 Endek Production (2015, July 11)

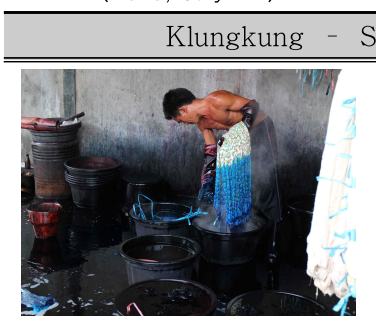

$\langle$ Fig. 70〉 Cold Dyeing (2016, January 21)

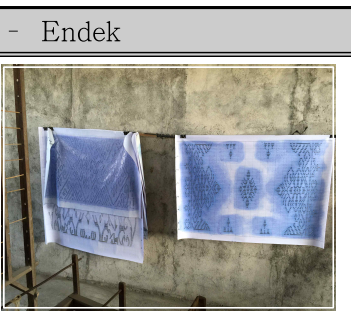

〈Fig 67〉 Endek Silk Screen (2015, July 11)

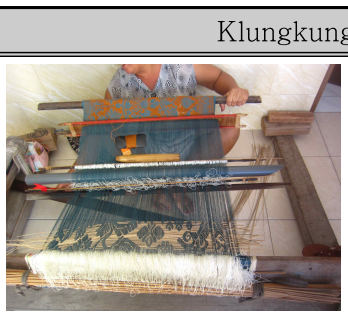

〈Fig 68〉 Songket Production (2015, July 11)

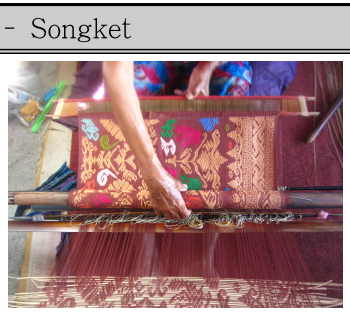

〈Fig. 69〉

Songket Patterm (2015, July 11)

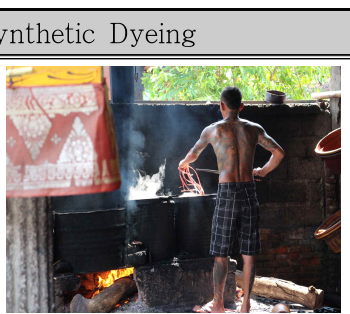

〈Fig. 71〉

Hot Dyeing (2016, January 21)

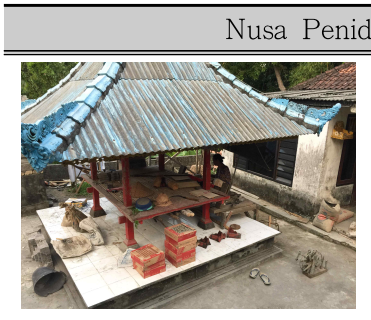

〈Fig. 74〉

Cepuk Production House (2015, July 7)

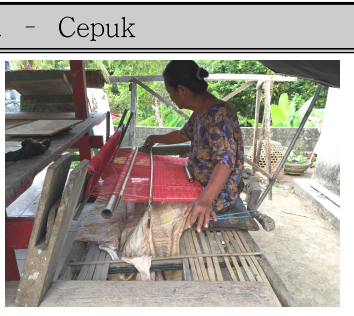

〈Fig. 75〉 Cepuk Production (2015, July 7) Satria Sub-district - Prada

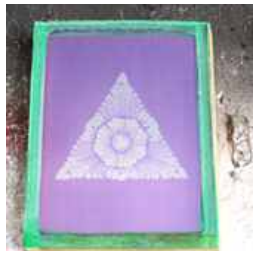

$\langle$ Fig. 72〉 Prada Silk Screen (2016, January 21)

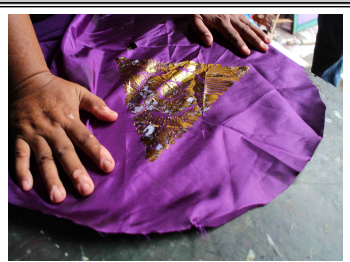

〈Fig. 73〉

Prada With Gold Foil (2016, January 21)

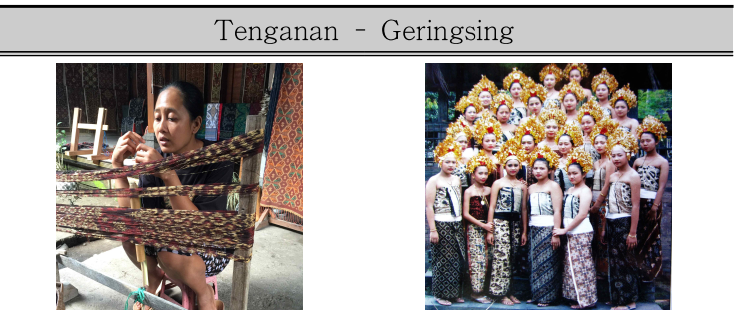

〈Fig. 76〉

Geringsing

Production

(2015, July 5)
〈Fig. 77〉

Geringsing Costume

(2015, July 5)

(Photographed by researcher, 2016: Table by researchers, 2017) 
tional making process surrounds the textile, from choosing the materials, weaving, colors, and patterns. Geringsing is only made from cotton. As for dyeing materials, only ripened candlenut and indigo dyeing are used in the neighboring village of Bugbug. "Only in Geringsing water and oil come together"(Daredia, 2012, p. 20). The cloth is dyed in candlenut oil resulting in a waxy cloth. Originally, the process of creating a cloth took eight to 10 years in order to follow the tradition and rules of Geringsing making. However, now, the process is shortened.

Geringsing cloths are produced with 14 patterns and three colors. Geringsing patterns are categorized by their repetitive arrangement (Daredia, 2012). In modern era, Geringsing cloths are still used and produced based on fundamental Hindu values until this day $\langle$ Fig. 76, 77〉.

\section{Conclusion.}

The conflation of culture and religion has made textiles an important aspect in Balinese life. The Balinese sacred cloths were defined based on their function in rites or festivals as temple decoration, as participants' and performers' costumes, and as a medium for protection and healing. This paper examined the aesthetics of Balinese sacred cloths. The developments of Balinese sacred cloths manifested in their manufacturing techniques, colors, and patterns. From these categories, Endek, Songket, Geringsing, Cepuk and Prada cloth were extracted. Field research in this paper observed Klungkung and Tenganan village, Nusa Penida Island, and Satria Sub-district.

Spirituality in Bali created a combination of the material and spiritual in the medium of textiles. Development of Balinese textiles occurred from the ancient era(i.e., before the $20^{\text {th }}$ century) until the modern era, which consisted of the colonization period by the Dutch and the Indonesian independence period. The ancient era was driven by religious values. The colonization period by the Dutch in the modern era was dominated by economic values, and the independence of Indonesia consisted of 'unity values.'

Design characteristics of Balinese textile are analyzed based on the manufacturing techniques, colors, and patterns. The techniques were classified as Weft Ikat, Double Ikat, weave with Supplementary Weft, and Prada. Based on their characteristics, weft Ikat signified 'worship,' double Ikat conveys 'status,' weave with Supplementary Weft indicated the 'spiritual,' and lastly, Prada was the symbol of 'royals,' Colors were examined from the history of Balinese textiles. Split into the ancient era and modern era, the ancient era's color characteristics were fixed, being restricted to the color red, black, and white. These colors were called Tridatu, referring to the three gods of Brahma, Vishnu, and Shiva. The color red or 'burgundy' was produced from Noni roots. Black was made from indigo leaves or pantone color 'dark navy'. The color white or Pantone color 'light taupe' was created from candlenut fruit. Red conveyed birth, black signified death and white symbolized life. The colors of the modern era were 'festive' with a combination of yellow, green, blue, and purple. The color yellow, or pantone color('lemon') was represented by the god of Mahadewa that meant sacred(tenget). Green or 'glistening green' was believed to be the source of everything, and blue 
or 'blue dazzle' signified fertility; both colors were representations of the god Vishnu. Lastly, purple, or 'tillandsia purple," signified no specific god, just signifying Balinese aesthetics. The characteristics of patterns were observed by its structure of geometric, natural, animal, and human shapes. In the ancient era, the patterns were fixed with small repetitions. In the modern era, the patterns are more complex with bigger and creative patterns.

Klungkung Village produces Endek and Songket cloths. The aesthetic characteristics of Endek cloths were a 'royal statement' and Songket cloths were a 'cultural heritage.' Tanglad Village produces cepuk cloths that appeared to be a 'protective guardian.' Satria Sub-district produces Prada cloths and signified 'opulence charm.' Tenganan Village produces Geringsing cloths and signified a 'legendary legacy.

This paper concludes that textiles serve as a medium between humans and god, between humans and ancestors, and between the living and the dead. These functions are preserved from the ancient textiles until this day. Although the patterns and colors of Balinese textiles have developed, the religious value of the cloths has persisted.

\section{Reference}

Bjork, P. (2013). Hospitality in Color: Healing Presence in Ceremonial Balinese Textiles (Dissertation). Available from ProQuest Dissertations and Theses database. (UMI No. 3551594)

Covarrubias, M. (1937). Island of Bali. Singapore. Singapore: Periplus Editions(HK) Ltd.

Daredia, N. (2012). Negotiated Power of Sacred balinese Textiles: How Identity Animates the Inanimate (Bachelor Thesis), Maryland Institute College of Art, USA.

Darta, I., Couteau, J., Bréguet, G. (2013). Time, Rites and Festivals in Bali. Indonesia: BABBOOKS

Davies, S. (2007). Balinese Aesthetics. The Journal of Aesthetics and Art Criticism(21-29). 65(1), 21-29. DOI: 10.1111/j.1540-594X.2007.00234.x

Gillow, J \& Dawson, B. (1995). Traditional Indonesian Textiles. London, Singapore: Thames and Hudson Ltd.

Hauser-Schaublin, B. Nabholz-Kartaschoff, M. Ramseyer, U. (1991). Balinese Textile. Hong Kong: Periplus Edition (HK) Ltd

Indigo paste (2015). Retrieved from http://sloparker.blog spot.k kr/2015/01/thailandblues.html

Nabholz-Kartaschoff, M-L(2008). The Textiles of Sembiran. In Brigitta Hauser-Schäublin and I Wayan Ardika(Eds). Burials, Texts and Rituals: Ethnoarchaeological Investigations in North Bali. Indonesia. Göttinger Beiträge zur Ethnologie Band 1, 69-117.

Noni Roots (n-d). Retreived from http://www.lionhearth erbs.com/herbs-a-z/morinda-root/

Pantone (1992). Pantone Textiles Color Specifier. USA: Pantone, Inc.

Soedjatmoko, R., Damais, S., Saputra, K. (1993). Bunga Rampai Wastra Bali. Bali, Indonesia: Himpunan Wastraprema

Sumiartini, K. (2015, July 5). Oral Statement Interview by researcher.

Wrońska-Friend, M. (2015). Balinese Textiles: For Gods and People. Lódź, Poland: Central Museum of Textiles in Lódź, Poland.

Widana, A. A. (2016, January 6). Oral Statement Interview by researcher

Widiawati, D. \& Rosandini, M. (2012). Natural Dyes on Indonesian Traditional Textiles - A Case Study: Geringsing Woven Fabric, In Tenganan Pengrisingan Village Bali. The Research Journal of the $\mathrm{Cos}^{-}$ tume Culture. 20(1), 111-120. 